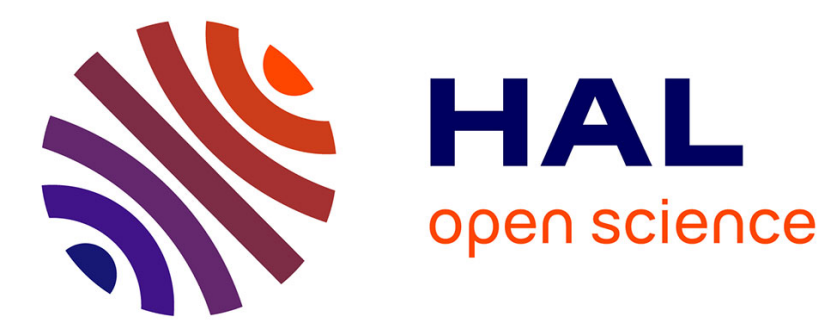

\title{
Impact of spatial differentiation of nitrogen taxes on french farms' compliance costs
} Anna Lungarska, Pierre-Alain P.-A. Jayet

\section{To cite this version:}

Anna Lungarska, Pierre-Alain P.-A. Jayet. Impact of spatial differentiation of nitrogen taxes on french farms' compliance costs. Environmental and Resource Economics, 2018, 69 (1), pp.1-21. 10.1007/s10640-016-0064-9 . hal-02627561

\section{HAL Id: hal-02627561 https://hal.inrae.fr/hal-02627561}

Submitted on 26 May 2020

HAL is a multi-disciplinary open access archive for the deposit and dissemination of scientific research documents, whether they are published or not. The documents may come from teaching and research institutions in France or abroad, or from public or private research centers.
L'archive ouverte pluridisciplinaire HAL, est destinée au dépôt et à la diffusion de documents scientifiques de niveau recherche, publiés ou non, émanant des établissements d'enseignement et de recherche français ou étrangers, des laboratoires publics ou privés.

\section{다(1)(2)}

Distributed under a Creative Commons Attribution - ShareAlikel 4.0 International 
Accepted final version of the paper published in Environmental and Resource Economics, DOI: 10.1007/s10640-016-0064-9.

Link: http://link.springer.com/article/10.1007/s10640-016-0064-9 


\title{
Impact of spatial differentiation of nitrogen taxes on French farms' compliance costs
}

\author{
Anna Lungarska and Pierre-Alain Jayet \\ INRA, UMR 210 Economie Publique, F-78850 Thiverval-Grignon, France
}

\begin{abstract}
The spatial differentiation of input-based pollution fees should in theory decrease compliance costs in the case of nitrate pollution of water bodies from agriculture because both the damage and the compliance costs vary over space. However, the empirical evidence in the literature does not agree on the extent of the potential savings from differentiation. We address this issue in the case of France, using a mathematical programming model of agricultural supply (AROPAj). The modeling approach used accounts for the spatial diversity of nitrate pollution and the heterogeneity of farming systems. Our results reveal the efficiency gains from differentiating pollution fees among polluters and water bodies. For instance, firm-specific and water body-specific taxes represent respectively $5.8 \%$ and $32.5 \%$ of farmers' gross margin in terms of compliance costs, whereas a uniform policy at the river-basin district or national level leads to major economic losses and abandonment of the agricultural activity. These results stem from the lower tax rates faced by farmers in less polluted areas, for scenarios based on spatial differentiation. Our estimates suggest that realistic regulation via input-based pollution fees should be differentiated in order to significantly reduce the financial burden on farmers of conforming to predefined pollution levels. Some potential adverse effects related to input-based taxation and land use change call for additional fine-scale nitrogen pollution regulation (e.g. limitations on crop switching).
\end{abstract}

\section{Introduction}

Every year French households spend between 1 billion and 1.5 billion euros (or 7-12\% of their water bill) on additional water treatment because of agricultural pollution (Commissariat Général au Développement Durable, 2011). In the most polluted areas, these costs can reach $€ 494$ per household annually. These figures do not include the negative financial impact on tourism or additional health expenditure. Although agricultural pollution has been addressed by numerous studies and public policies, the problem persists. One possible instrument for reducing agricultural pollution at source would be an environmental tax. The socially optimal level of such pollution fees should be spatially and individually differentiated, since both damage and compliance costs vary over space. In practice, environmental taxes can rarely be optimal (as Pigou 1937 acknowledged); nevertheless, their second-best variants offer cost-effective solutions. In this paper we investigate the potential environmental and economic effects of the spatial differentiation of a pollution fee in France in the context of the European Union (EU) Water Framework Directive (EU WFD, European Community 2000), the EU Nitrates Directive (Council of the European Communities, 1991) and French national legislation.

With regard to nitrate pollution of water bodies, the damage and the abatement costs are unknown. Hence regulation could be formulated following Baumol and Oates (1971), where a uniform standard is defined and the most cost-effective way of achieving it is applied. Nitrate pollution is measured at a water body scale. Water bodies and the dynamics that define their respective nitrate pollution levels can differ widely. If the 
policy-maker has to introduce a unique Pigouvian fee for more than one water body and is obliged to respect the same environmental standard in all cases, then the highest tax should be imposed so that the standard is universally enforced. This tax would restrain polluting activity more than necessary for water bodies where the standard could be complied with at a lower cost. Furthermore, the various sources of nitrate leaching have differing effects on different water bodies, depending on their location and water run-off. Thus farmers' individual contribution to the nitrate concentration in a given water body varies in accordance with the physical properties of their land. In such a situation, if the environmental issue is to be tackled by means of Pigouvian fees, Tietenberg (1974) and Xepapadeas (1992) show theoretically that taxation schemes are more efficient if spatial heterogeneities are taken into account. Numerous studies evaluate the cost-effectiveness of such policies in cases of nitrate and/or phosphate concentrations in water. However, the evidence from empirical studies is contradictory.

In the present study we use a combination of a mathematical programming model of French agricultural supply (AROPAj, Jayet et al., 2015) and geographical information systems, enabling us to simulate the effects of tax differentiation for multiple water bodies and a variety of agricultural production systems. Our results confirm that differing tax rates among water bodies and economic agents have substantial advantages. For instance, firm-specific pollution fees and water body-specific rates can lead to respective reductions in farmers' profits of some $5.8 \%$ and $32.5 \%$, whereas uniform rates at river-basin district (RBD) and national levels could lead to major economic losses and abandonment of farming activity. The greater cost-effectiveness of the former two policies is due mainly to the lower tax rates applied in less polluted areas. Thus farming is constrained only in areas subject to anthropogenic pressure.

Previous studies focus on a single water body and do not take account of animal manure as a source of organic nitrogen. For instance, Westra and Olson (2001) use a positive mathematical programming model of a stylized watershed for two different crops, phosphorous effluents and tax differentiation based on "agroecoregions", which are distinguished by their edaphic and climatic conditions. The study by Lacroix et al. (2010) is based on the STICS crop model combined with an economic model, and tests the effects of soil/practice differentiation of policies for a given water body. These two studies show that tax differentiation can produce substantial efficiency gains. Fleming and Adams (1997) argue that the benefits might be insufficient to cover the higher transaction costs involved. The tax distinction in the latter study is based on different soil types, and their findings are in line with those in Helfand and House (1995). Helfand and House (1995) also use a crop model (EPIC) to simulate the nitrate effluents from lettuce for two soil types, and they link these results to a profit maximizing linear program representing farmers' decisions. Claassen and Horan (2001) use endogenous prices, which amplify the differences between uniform and non-uniform policies. Xabadia et al. (2008) introduce time into their analysis of stock pollution, in order to study the dynamic effects on technology and land use. With the exception of Fleming and Adams (1997) and Westra and Olson (2001), most empirical studies of tax differentiation consider a single crop, and thus neglect the effects on land use change (Goetz et al., 2005).

Land use change in the context of input-based taxation proves to be an important consideration when addressing nitrate pollution from agriculture. Farmers adapting to new input price vectors are able to switch to crops that require less nitrogen but are also less efficient in fixing it. Thus the introduction of such crops could lead to more 
nitrate leaching compared to the business-as-usual state. The study by Jayet and Petsakos (2013) demonstrates this adverse effect of input-based taxation in the case of the SeineNormandie RBD. Because our research is conducted on a finer geographical scale and for all six French RBDs, we encounter this effect in a number of cases. However, our results show that its extent is rather limited. Nevertheless, additional site-specific regulations may be needed to address this issue.

The methodology we employ allows us to differentiate tax levels for a number of water bodies. To our knowledge, this is the first study to explicitly model animal manure in the context of tax differentiation and nitrate pollution. The agricultural supply model used considers different levels of production heterogeneity such as soil type, crop, climate, and other productive and economic specificities of agriculture. This methodology allows us to investigate the effects of input-based water body-specific pollution fees. The studies by Jayet and Petsakos (2013) and Bourgeois et al. (2014) are based on the same bioeconomic model as our investigation. The former is focused on a comparison of the nitrate emissions abatement costs under different EU Common Agricultural Policy (CAP) scenarios. Bourgeois et al. (2014) compare the cost-effectiveness of a uniform nitrogen tax and a mixed policy (a tax on nitrogen and a subsidy on a low-input plant, miscanthus) in relation to abatement of the pollutants resulting from nitrogen fertilization.

In this paper we first provide a broad description of the case of nitrate pollution in France, and related environmental legislation. French legislation does not allow implementation of the firm- and water body-specific taxation scheme derived in Section 3. In Section 4, we compare the results of four policy scenarios for France at the scale of RBDs: 1) a benchmark case with farmer-specific tax rates in polluted areas; 2) a differentiated fee applicable in RBDs in polluted areas; 3) unique fees per RBD in polluted areas; and 4) a uniform national tax rate in polluted areas. In order to approximate abatement costs, we use the farmer's losses in gross margin and tax revenues.

\section{Background}

Nitrate pollution is unevenly distributed across French territory, with the highest nitrate loads found in the north and northwest of the country. Concentration levels in certain regions exceed the EU norm of $50 \mathrm{mg} / \mathrm{l}$. In 2013, 55\% of utilized agricultural land in France was classified as a Nitrate Vulnerable Zone (NVZ) on the basis of the EU Nitrates Directive (Council of the European Communities, 1991). NVZs are defined as "areas of land which drain into polluted waters or waters at risk of pollution and which contribute to nitrate pollution". Nitrates occur naturally in water, but in small quantities. A groundwater concentration of less than $25 \mathrm{mg} / \mathrm{l}$ is considered natural (Viennot et al., 2009) or subject to low anthropogenic pressure.

France has institutions - the RBD agencies ${ }^{1}$ - dedicated to governing the country's water resources. RBD agencies cover the RBD division recommended by the EU WFD. Figure 1 depicts the six RBD agencies in France, subdivided into hydrological sectors. RBD agencies are empowered to collect pollution fees and to distribute subsidies and loans on their territory. Decisions are made by the Agencies' respective parliaments, which represent the different water users.

Recent changes to the French Environmental Code address non-point source pollution

\footnotetext{
${ }^{1}$ Agences de l'eau
} 


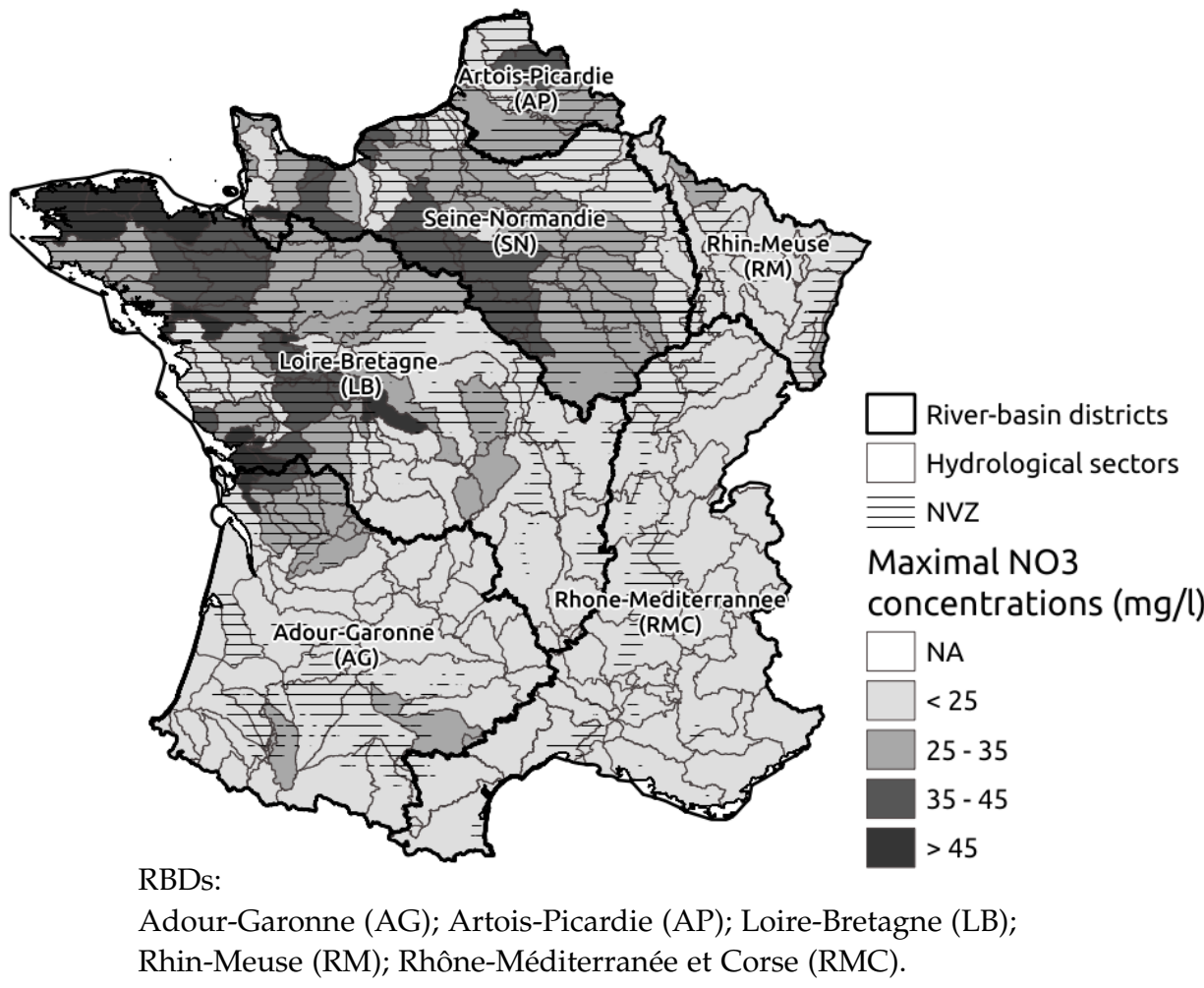

Figure 1: River-basin district boundaries, NVZs and maximal nitrate concentration (maximal value between groundwater and surface water concentrations in 2007, Service de l'observation et des statistiques, 2011)

and introduce pollution fees on livestock units (LU) ${ }^{2}$. Article L213-10-2 of the Environmental Code states (Legifrance, 2014) that pollution fees are set by RBD agencies at a coherent geographical unit level and with respect to: 1) the state of water bodies, 2) the risk of infiltration of pollutants, 3) prescriptions by water or other police, and 4) objectives decided at the RBD level. Following this legislative framework, we focus our study on the economic effects of geographically differentiated tax on nitrogen fertilizers. Such taxes have certain limitations originating from asymmetric information on input use. There are incentives for agents subject to lower taxation rates to resell fertilizers to others (Helfand and House, 1995), making the problem one of moral hazard. In France, this is less problematic since farmers in NVZs are obliged to keep records of the amounts of nitrogen applied. False declarations can result in exclusion from the Single Payment Scheme (SPS) of the EU CAP. This system allows the tax to be levied on the basis of farmers' declarations. Assuming a competitive market for fertilizers, in the short run the input supply curve should remain unaffected by the policy.

\section{Theoretical model}

The starting point of our static theoretical model is provided by Shortle and Horan (2002). They consider different cases of environmental constraints (damage or concentration levels) and policy designs (input or ambient-based instruments). Our study uses a

\footnotetext{
${ }^{2}$ The pollution fee is applied when there are more than $1.4 \mathrm{LU}$ per ha of utilized agricultural land on the farm. The charge is levied for units exceeding a certain threshold (40 units).
} 
concentration constraint and an input-based taxation scheme. It draws also on Segerson (1988) in that we administer the environmental policy according to ambient pollution levels. The objective of the environmental tax here is not allocative efficiency among producers but only conformity to the imposed norm at the lowest possible cost to society.

Water pollution results from point and non-point source nitrate leaching. For simplicity, our theoretical model addresses only non-point source nitrate leaching originating from farmers' use of mineral fertilizers and animal manure. The framework includes a set of farms (indexed as $i=1, \ldots, i, \ldots, n$ ) characterized by specific profit functions and geographically referenced positions associated with water bodies $(w=1, \ldots, l)$, unlike the study by Shortle and Horan (2002), which considers only one water body. A single farm can have fields connected to different water bodies and subject to different physical conditions (e.g. soil quality, topography). Farmers maximize their profit $\left(\pi_{i w}\right)$ by choosing the levels of their inputs $\left(x_{i w}\right)$. We apply the standard assumption for a profit function namely that it is concave $\left(\partial^{2} \pi_{i w} / \partial x_{i w}^{2}<0\right)$, and assume the existence of internal solutions for $\partial \pi_{i w} / \partial x_{i w}=0$ where $x_{i w}>0$. Nitrate emissions, $r_{i w}$, of the farm $i$ affecting the water body $w$ are determined by input use, $x_{i w}$, site characteristics of the water body, such as soils and slope, and stochastic environmental variables $\left(z_{i w}{ }^{3}\right)$ following the relation: $r_{i w}\left(x_{i w}, z_{i w}\right)$.

Emissions define pollution concentrations following a water body-specific pollution fate and transport function, i.e., $a_{w}\left(r_{1 w}, \ldots, r_{i w}, \ldots\right)$ where $\partial a_{w} / \partial r_{i w} \geq 0 \forall i, w$. The policymaker introduces a uniform ${ }^{4}$ environmental standard $(L)$ limiting the pollution. Thus we take into account only the pollution concentration and not, as in Shortle and Horan (2002), the resulting damage to society. The environmental standard is assumed to be the threshold value above which pollution is unacceptable to society. The policy-maker's program involves maximizing the sum of the farmer's profits and an environmental constraint comparing the expected pollution concentration $\left(\mathbb{E}_{z} a_{w}\right)$ with the environmental standard $(L)$.

$$
\begin{array}{ll} 
& \max _{x_{i w}} \sum_{i} \sum_{w} \pi_{i w}\left(x_{i w}\right) \\
\text { s.t. } \forall w \quad & \underset{z}{\mathbb{E}} a_{w} \leq L \quad\left(\lambda_{w}\right)
\end{array}
$$

First, we focus on the case where the optimal solution is obtained with a non-binding environmental constraint $\left(\mathbb{E}_{z} a_{w}<L\right)$ for the $w$-th water body. This implies a zero value for the related dual variable (i.e. $\lambda_{w}^{*}=0$ ). The first order optimality condition (FOC) related to the input is presented in Equation (2).

$$
\frac{\partial \pi_{i w}\left(x_{i w}^{*}\right)}{\partial x_{i w}}=0 \quad \forall i, w
$$

The asterisks on the primal and dual variables denote the solution of this program. Hence, in the case where the environmental constraint is non-binding, the policy-maker's FOC fully coincides with farmers' private FOC.

The above statement does not hold if the environmental constraint is binding $\left(\lambda_{w}^{*}>0\right)$ as shown in Equation (3).

\footnotetext{
${ }^{3}$ See Shortle and Horan (2002) for the full specification of the emission function

${ }^{4}$ As the one defined by the European Union Nitrates Directive of $50 \mathrm{NO}_{3} \mathrm{mg} / \mathrm{l}$
} 


$$
\mid \begin{gathered}
\underset{z}{\mathbb{E}} a_{w}=L \\
\frac{\partial \pi_{i w}\left(x_{i w}^{*}\right)}{\partial x_{i w}}=\lambda_{w}^{*} \underset{z}{\mathbb{E}} \frac{\partial a_{w}}{\partial r_{i w}} \frac{\partial r_{i w}}{\partial x_{i w}} \quad \forall i, w
\end{gathered}
$$

Equation (3) balances the marginal profit and the expected contribution to pollution concentration of an additional unit of $x_{i w}$. These figures are not uniform across geographical space. Consequently, if the policy-maker is addressing nitrate pollution via a tax it will in principle be $i w$-dependent. The introduction of a fee on polluting activities modifies the farmer's objective function. Farmers maximize after-tax profit $\pi_{i w}\left(x_{i w}\right)-t_{i w} x_{i w}$. The FOC (Equation (4)) leads to equality between the marginal profit from the activity and the tax.

$$
\frac{\partial \pi_{i w}\left(x_{i w}^{*}\right)}{\partial x_{i w}}=t_{i w}
$$

From Equations (3) and (4), we can define the level of the tax which has a non-zero value when the environmental constraint is binding. Equation (5) gives us a water body and firm-specific tax that assures conformity to the norm on average.

$$
t_{i w}=\lambda_{w} \underset{z}{\mathbb{E}} \frac{\partial a_{w}}{\partial r_{i w}} \frac{\partial r_{i w}}{\partial x_{i w}}
$$

Although Equation (5) is appealing, it hides a degree of complexity. Bourgeois et al. (2014) estimate functions for nitrate emissions for the six French RBDs and for different crops. The functions are assumed to be linear, and the coefficients (intercept and slope) differ widely between crops and RBDs (soil and climate conditions). Furthermore, nitrate emissions are dependent on the type of fertilizer and on animal manure application as well as climatic conditions. Hence defining a first-best input based tax is extremely difficult. These complications can be overcome only by basing the tax directly on nitrate emissions, which unfortunately are difficult to assess in the real world. The policies studied aim to regulate the use of marketed and on-farm produced nitrogen by introducing a tax on mineral fertilizers and livestock units.

Equation (5) shows also that the level of the tax is indexed $t_{i w}$ because it is firm- and water body-specific. Note that firm-specific tax differentiation is illegal in France as a result of the fiscal equity principle. For this reason, in Section 4, we investigate pollution fees differentiated solely between water bodies and compare them to a benchmark scenario.

\section{A feasible water body-specific pollution tax on nitrogen fertilizers and livestock in France}

\subsection{Hypothesis}

Water bodies presented in the model in Section 3 are assumed to coincide with hydrological sectors (hereafter hydrosectors) or subdivisions of RBD. There are more than 200 hydrosectors in metropolitan France (Figure 1). As discussed in Section 3, the pollution fee should be firm- and water body-specific, but French law does not permit such specification. However, the geographical differentiation of water pollution fees is established in the Environmental Code and has been implemented. For instance, the Seine-Normandie 
RBD agency applies different coefficients to its industrial pollution fees depending on firms' locations and the state of the water ${ }^{5}$.

\section{Identifying zones with potentially binding cases}

Equation (5) relates the pollution charge level to the dual value of the environmental constraint $\left(\lambda_{w}\right)$ and the marginal effect of the nitrogen input on pollution concentrations. The pollution fee is applied only when the environmental constraint is binding $\left(\lambda_{w}>0\right)$. In order to determine whether or not the constraint is binding, we intersect hydrosectors with NVZs. If a NVZ is present in the territory of a hydrosector, we assume that potentially $\lambda_{w}>0$. Figure 1 shows the geographical distribution of the NVZ and the maximal concentrations between surface and groundwater in the hydrosectors (Service de l'observation et des statistiques, 2011). We consider a given hydrosector to be located in a polluted area if there are NVZs on its territory.

\section{Hydrosector-specific tax}

Given the regulatory limits, we focus on a water body-specific pollution fee. Equation (5) imposes a tax equal to the expected marginal pollution concentration resulting from the application of one supplementary unit of input by the $i$-th firm in the $w$-th water body multiplied by $\lambda_{w}$. In this case, a water body-specific fee will equal the marginal profit of farmers across the water body.

In order to evaluate the marginal effect of nitrogen on pollution concentrations, we use the Simplified Vulnerability Index (Network Persistence and Development Index, IDPR) developed by $\mathrm{BRGM}^{6}$. The index range spans 0 to 2000 where lower values indicate high infiltration of surface water in groundwater. Values above 1000 mark the predominance of water run-off into adjacent surface water bodies. Using geographical information systems, we aggregate IDPR at the hydrosector level. The IDPR is used in France to make broad estimates of the vulnerability of groundwater. ${ }^{7}$

In our study, we apply this index in a statistical model that explains the observed nitrate concentrations in surface water by the average quantity of fertilizers and the average number of livestock units at the hydrosector scale. This model allows us to approximate the marginal contribution to nitrate concentration of one extra unit of fertilizer or livestock.

\section{A water body scale statistical model of nitrate concentrations}

We propose a statistical model based on Equation (6) estimated using ordinary least squares (OLS). The model relates the observed nitrate concentrations (surface water) to the two agricultural sources of nitrogen: mineral fertilizers and livestock manure; and to the IDPR vulnerability coefficient.

$$
\begin{aligned}
\text { Surface water } \mathrm{NO}_{3} \text { concentration }_{w}=\alpha_{0} & +\alpha_{1} I D P R_{w}+\alpha_{2} \text { Fertilizers }_{w} * I D P R_{w} \\
& +\alpha_{3} \text { Livestock }_{w} * I D P R_{w}+\epsilon_{w}
\end{aligned}
$$

\footnotetext{
${ }^{5}$ Seine-Normandie RBD agency http://www . eau-seine-normandie.fr/index .php?id=5145

${ }^{6}$ Bureau de recherches géologiques et minières, http://www.brgm.fr/

${ }^{7}$ Numerous reports of the BRGM (http://brgm.fr) use a combination of IDPR and depth in the unsaturated zone to evaluate vulnerability (e.g. the simplified vulnerability assessment of the SN RBD available at http: //sigessn.brgm.fr/spip.php?article71). In this study different weights are assigned to the IDPR and depth in the unsaturated zone. Our study uses only the IDPR.
} 
Data for the explanatory variables is taken from the AROPA $j$ agricultural supply-side model (see Subsection 4.2). The statistical model performs well in terms of explained variation $\left(R^{2}\right.$ of 0.62$)$, and all the coefficients are significant at the $0.1 \%$ confidence level. The actual levels of concentration (indexed in ascending order) are plotted on Figure $2 \mathrm{~b}$. The dashed line connects the predicted values. Figure $2 \mathrm{~b}$ shows that the model tends to underestimate the concentrations at values above $23 \mathrm{mg} / \mathrm{l}$. High concentration levels are mostly observed in the Loire-Bretagne RBD where there are numerous farms specializing in intensive animal breeding (e.g. pig farms in Brittany). Such farms are represented in our agricultural supply-side model. However, since they are off-soil, they are difficult to locate through the spatialization technique we use (described later in Subsection 4.2), which is based on land use information. The observed surface pollution values do not exceed $50 \mathrm{mg} / \mathrm{l}$, and are above the norm for groundwater in only six hydrosectors. We focus on surface water since the statistical model performs better at this level of nitrate pollution ( $R^{2}$ of 0.62 versus 0.35 for groundwater). On average, groundwater pollution is $25 \%$ higher than surface water pollution, and the two are positively correlated (Pearson $r$ of 0.68 ). Because of the high level of correlation between the two concentration values, we take surface water concentrations to be a good proxy for groundwater pollution. These limitations of the statistical model require lowering the value of the environmental constraint. The norm we are enforcing is $25 \mathrm{mg} / \mathrm{l}$ which, according to our statistical model, is infringed by 24 of the 169 hydrosectors considered.

In our model specification, we implicitly suggest that the relation between concentrations and inputs is linear. ${ }^{8}$ This assumption is needed to simulate the tax schemes in the AROPAj model (see Subsection 4.2). The true relation between nitrogen sources and concentrations is beyond the scope of the present study. However, the high coefficient of determination of our statistical model makes us confident about our approximations. There is no doubt that panel data on concentration levels at the hydrosector scale would provide more valuable insight. However, to our knowledge, this information is not currently available.

This statistical model has two purposes. First, based on the estimates of Equation (6) we can parameterize the environmental constraint in farmers' profit maximization problem and thus deduce the values of $\lambda_{w}$. Second, the estimated coefficients in Equation (6) are used to approximate the marginal contribution of the additional unit of fertilizer or livestock. By combining the dual value and the estimated coefficients we obtain the values for the farmer-specific tax. Note that by using the interaction terms between fertilizers and the IDPR, and the livestock units and the IDPR (Equation (6)), we obtain hydrosectorspecific marginal effects.

\section{Taxation scheme scenarios}

In order to evaluate the potential benefits of tax differentiation, we estimate and compare the loss of gross margin for the following taxation schemes:

1. A farmer-specific tax rate for farmers in polluted areas ("Tax GT");

2. A uniform tax rate per hydrosector in polluted areas ("Tax hydrosectors");

3. A uniform tax rate per RBD in polluted areas ("Tax RBD");

4. A uniform national tax rate in polluted areas ("Tax National").

\footnotetext{
${ }^{8} \mathrm{~A} \log$-linear specification gives an adjusted $R^{2}$ of 0.54 and an exponential model 0.72 . Both models underestimate the highest levels of concentration.
} 


\begin{tabular}{|c|c|c|c|c|}
\hline \multicolumn{4}{|l|}{ (Intercept) } & $\begin{array}{l}35.56^{* * *} \\
(242)\end{array}$ \\
\hline \multicolumn{4}{|l|}{ IDPR } & $\begin{array}{l}-5.55^{* * *} \\
(0.41)\end{array}$ \\
\hline \multicolumn{4}{|l|}{ Fertilizers $^{\dagger} *$ IDPR } & $\begin{array}{l}22.13^{* * *} \\
(3.62)\end{array}$ \\
\hline \multicolumn{4}{|l|}{ Livestock $^{\dagger} *$ IDPR } & $\begin{array}{l}1.66^{* * *} \\
(0.17)\end{array}$ \\
\hline \multicolumn{4}{|l|}{ Number of observations } & 169 \\
\hline \multicolumn{4}{|l|}{$R^{2}$} & 0.62 \\
\hline \multicolumn{4}{|l|}{ adj. $R^{2}$} & 0.62 \\
\hline \multicolumn{4}{|l|}{ Resid. standard deviation } & 6.43 \\
\hline \multicolumn{5}{|l|}{ Residuals distribution: } \\
\hline Min & Median & $3 Q$ & Max & \\
\hline$-13.73-4.15$ & -0.58 & 3.14 & 22.48 & \\
\hline \multicolumn{5}{|c|}{$\begin{array}{l}\text { Standard errors in parentheses } \\
{ }^{*} \text { significant at } p<.05 ;{ }^{* *} p<.01 ;{ }^{* * *} p<.001 \\
+ \text { Fertilizers and livestock are expressed in units per hectare of } \\
\text { the geographical surface of the hydrological sector. }\end{array}$} \\
\hline
\end{tabular}

(a) Statistical model (OLS) of nitrate pollution concentrations $\left(\mathrm{NO}_{3} \mathrm{mg} / \mathrm{l}\right)$ observed in surface water in France.

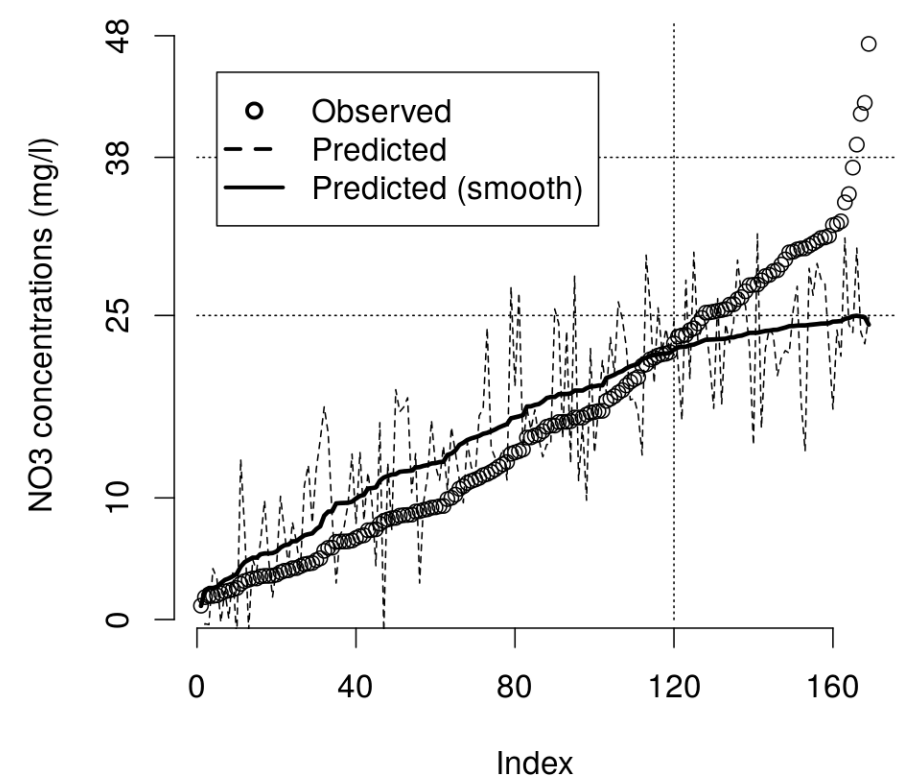

(b) Plot of the observed nitrate concentrations $\left(\mathrm{NO}_{3} m g / l\right)$ in surface water and the predicted values.

Figure 2: Statistical model of nitrate pollution concentrations $\left(\mathrm{NO}_{3} \mathrm{mg} / \mathrm{l}\right)$ observed in surface water in France. 


\subsection{Methodology}

In our study we use the AROPAj agricultural supply model combined with the STICS crop model. AROPAj is a static optimization model based on classical microeconomic assumptions and uses the Farm Accountancy Data Network (FADN) database. A detailed description of the model is provided in Jayet et al. (2015). The economic agents are farms grouped in representative "group-types" (GTs) depending on their activity, economic size, and altitude. Such models are commonly used quantitative methods applied to agricultural, environmental, and resource economics (Kaiser et al., 2011). Initially, AROPAj is structured as an assembly of mixed integer linear programming models. Non-linearity occurs through integer variables and the use of dose-response functions linking nitrogen inputs and crop yields.

$$
\begin{array}{ll} 
& \max _{x_{i}} \pi_{i}\left(x_{i}\right) \\
\text { s.t. } & A_{i} x_{i} \leq s_{i} \\
& x_{i} \geq 0
\end{array}
$$

Equation (7) is a descriptive summary of the optimization program of GTs in AROPAj. Each economic agent in the model maximizes its gross margin $\left(\pi_{i}\right)$ or the difference between revenues and variable costs. The optimization program is bounded by technical and structural constraints, some of which are related to the EU CAP. GTs in AROPAj are indexed as $i$ as are farmers in the theoretical model in Section 3. The vector $x_{i}$ has a broader meaning, in that it integrates the productive activities of economic agent $i$. In our case, the activities of interest are mineral fertilization and animal breeding. Livestock manure available to the farm is accounted for by explicit model variables and is applied to fields where there is crop activity. The matrix $A_{i}$ represents the input-output constraints of the profit maximization problem and the right-hand side is given by the vector of capacities $s_{i}$. We use the V2 version of the model (Jayet et al., 2015) with the 157 grouptypes comprising French agriculture.

To render economic agents more adaptive to policy and/or price shocks, dose-response functions are introduced for each crop-group-type combination, (Godard et al., 2008). These functions are estimated through the STICS crop model (Brisson et al., 1998). An additional block is dedicated to the nitrogen balance and related to the $\mathrm{N}$-to-yield functions. $\mathrm{N}$-inputs are mineral fertilizers and five $\mathrm{N}$-organic compounds sourced from manure. Jayet and Petsakos (2013) use the same method in their study of nitrogen input-based taxation. A similar approach is found in the literature (Helfand and House, 1995; Larson et al., 1996; Martínez and Albiac, 2006).

STICS estimates crop yields for different quantities of $N$ fertilizer at parcel level. The crop model entries include climate, soil, irrigation and some agronomic variables (e.g. varieties, sowing and harvest dates). GTs face specific biophysical conditions, and doseresponse functions are estimated individually for each GT. The functional form used is exponential, increasing and concave (Equation (8)). It is therefore compatible with the standard economic assumption of decreasing marginal productivity of inputs ${ }^{9}$. The function calls for the sum of the mineral and organic $N$. Nitrogen sources are indexed by $o$ and the "rate of increase" of the function is captured by the parameter $\tau_{i c o}$ (crops

\footnotetext{
${ }^{9}$ The literature uses some other specifications for dose-response functions (Gallego-Ayala and Gómez-Limón, 2009; Martínez and Albiac, 2006); they are also increasing and concave.
} 
are indexed by $c$ ). This parameter is estimated initially for a standard mineral fertilizer and weighted by an agronomic rule of equivalence between $N$ sources. The quantities $Y_{i}^{\min }$ and $Y_{i}^{\max }$ represent the minimal and the maximal yield and do not depend on the type of $N$. Maximal yield is estimated asymptotically as the yield obtained under no $N$ limitations for the crops. The yield when $N_{o}=0, \forall 0$ gives the parameter $Y_{i}^{\min }$.

$$
Y_{i}=Y_{i}^{\max }-\left(Y_{i}^{\max }-Y_{i}^{\min }\right) e^{-\sum_{o} \tau_{i c o} N_{o}}
$$

where

$$
\begin{aligned}
& Y_{i} \text { is yield, } Y_{i} \in\left[Y_{i}^{\min } ; Y_{i}^{\max }\right] \text {, and } \\
& N_{o} \text { is the quantity of each type of nitrogen applied }\left(N_{o} \geq 0\right) .
\end{aligned}
$$

This procedure is applied to nine crops: common wheat, durum wheat, barley, maize, rapeseed, sunflower, soybean, potato, and sugar beet (Leclère et al., 2013). Thus the model solves for the optimal mineral fertilizer quantities, crop allocation, livestock units and their feed, and gross margins among others. The introduction of dose-response functions makes the input use decision endogenous. This methodology increases the flexibility of economic agents while taking account of the technical constraints characterizing agricultural activities. However, since it is a supply-side model, no feedback on the prices of inputs and outputs is considered. Furthermore, farmers' choice of crops is limited to the short run, even though crop rotations are implicitly accounted for in the model's constraints set.

Nitrate emissions are also evaluated by the STICS model. They represent $\mathrm{NO}_{3}^{-}$ion losses at root level. Bourgeois et al. (2014) estimate linear emission functions (Equation (9)) based on the simulated results from STICS for each GT $i$ and each of the nine crops, $c$, mentioned above. Since each GT is associated with only one FADN region, the GT-specific coefficients $\beta_{0 i c}$ and $\beta_{1 i c}$ are estimated for the specific climatic and edaphic conditions of the region to which the GT belongs.

$$
r_{i}(N)=\beta_{0 i c}+\beta_{1 i c} N
$$

Another important aspect of AROPAj is the inclusion of livestock in the model. Since animal manure is a source of nitrogen, we allow farmers to adjust their livestock capital in the range of $\pm 15 \%$ of the initial values. This limitation on possible livestock variation is necessary because the model does not account for the fixed capital related to animal breeding. Hence, we are considering variations greater than $\pm 15 \%$ to be outside the model's calibration interval.

Livestock manure application is limited to $170 \mathrm{~kg}$ of nitrogen per hectare per year for the territories in NVZs (Council of the European Communities, 1991). This restriction is accounted for in the model. Since our economic agents are all associated with FADN regions where there are NVZs, and since the exact location of the agents within the region is in principle unknown, we apply this restriction to all GTs. We find this limitation rarely binding except in regions with a large manure excess that lie within NVZs.

The various fertilizers (ammonium nitrate, urea, etc.) available on the market are represented by an $N$-compound fertilizer for each group-type and each crop. Mean $N$ content for this $\mathrm{N}$-compound fertilizer is about $18 \%$ for a price of around $€ 1$ per $\mathrm{kg}$ of 


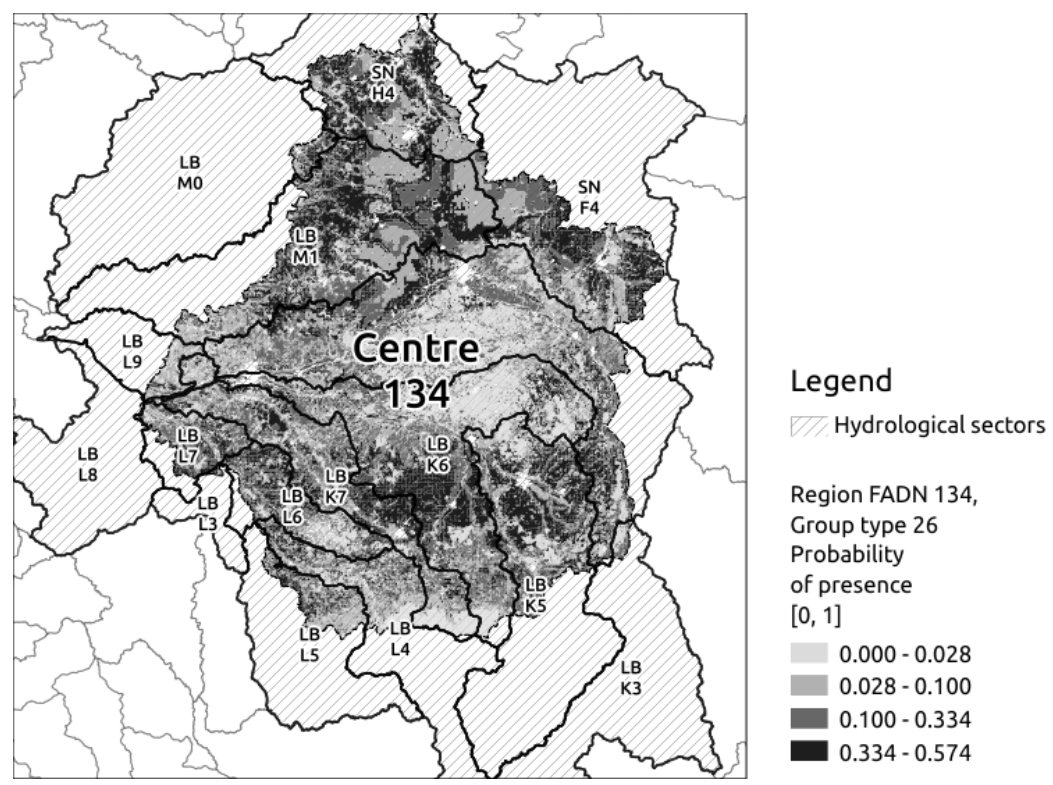

Figure 3: The intersection between hydrological sectors, the FADN region 134 and the probabilities of presence for the farm group-type 26.

$N$. This corresponds roughly to the price of nitrogen units in ammonium nitrate (NPK of 33.5-0-0). Martínez and Albiac (2006) use a similar value (€0.90 per $\mathrm{kg}$ ). The model provides estimates for crop areas, yields, amount of nitrogen used, nitrate emissions, and farmer's gross margin, and accounts for five types of animal manure. Results are obtained for each GT associated with a unique FADN region.

\section{Spatialization of AROPAj results}

The exact geographical location of GTs within the region is unknown due to the FADN data privacy policy. Thus AROPAj results are spatialized (Cantelaube et al., 2012) following the technique in Chakir (2009). FADN regions are divided into a $100 \mathrm{~m} \times 100 \mathrm{~m}$ grid. First, remote-sensing data for land cover $^{10}$ is combined with land use survey data ${ }^{11}$, and data on weather, ${ }^{12}$ and soils ${ }^{13}$. A multinomial logit model is estimated relating land use (crop) with the other physical data. Finally, the probabilities of GTs are defined for each cell (Cantelaube et al., 2012).

The present study is interested in the hydrosector level, which does not coincide with FADN regions. In order to represent the results at that scale, we use the grids obtained through the spatialization procedure already described, and aggregate the data with respect to hydrosector borders and area. Martínez and Albiac (2006) adopt a similar approach and use remote-sensing and crop-field surveys for the spatialization of their model. The uncertainty of the location of GTs is crucial. Since our objective is to define a hydrosector-specific tax, all GTs potentially present in the hydrosector are taken into account. Figure 3 represents the intersection between hydrosectors and the French FADN "Centre" region. The darker the filled polygons, the greater the probability of the presence of a given GT in the polygon.

\footnotetext{
${ }^{10}$ Corine Land Cover, for information see: http://www.eea.europa.eu/publications/COR0-landcover

${ }^{11}$ LUCAS, for information see: http://ec.europa.eu/eurostat/web/lucas/overview

${ }^{12}$ JRC MARS AGRI4CAST Interpolated Meteorological Data, for information see: http://agri4cast.jrc . ec. europa.eu/DataPortal/Default.aspx

${ }^{13}$ JRC EUSOILS, Panagos et al. (2012), for information see: http://eusoils .jrc.ec. europa.eu/
} 


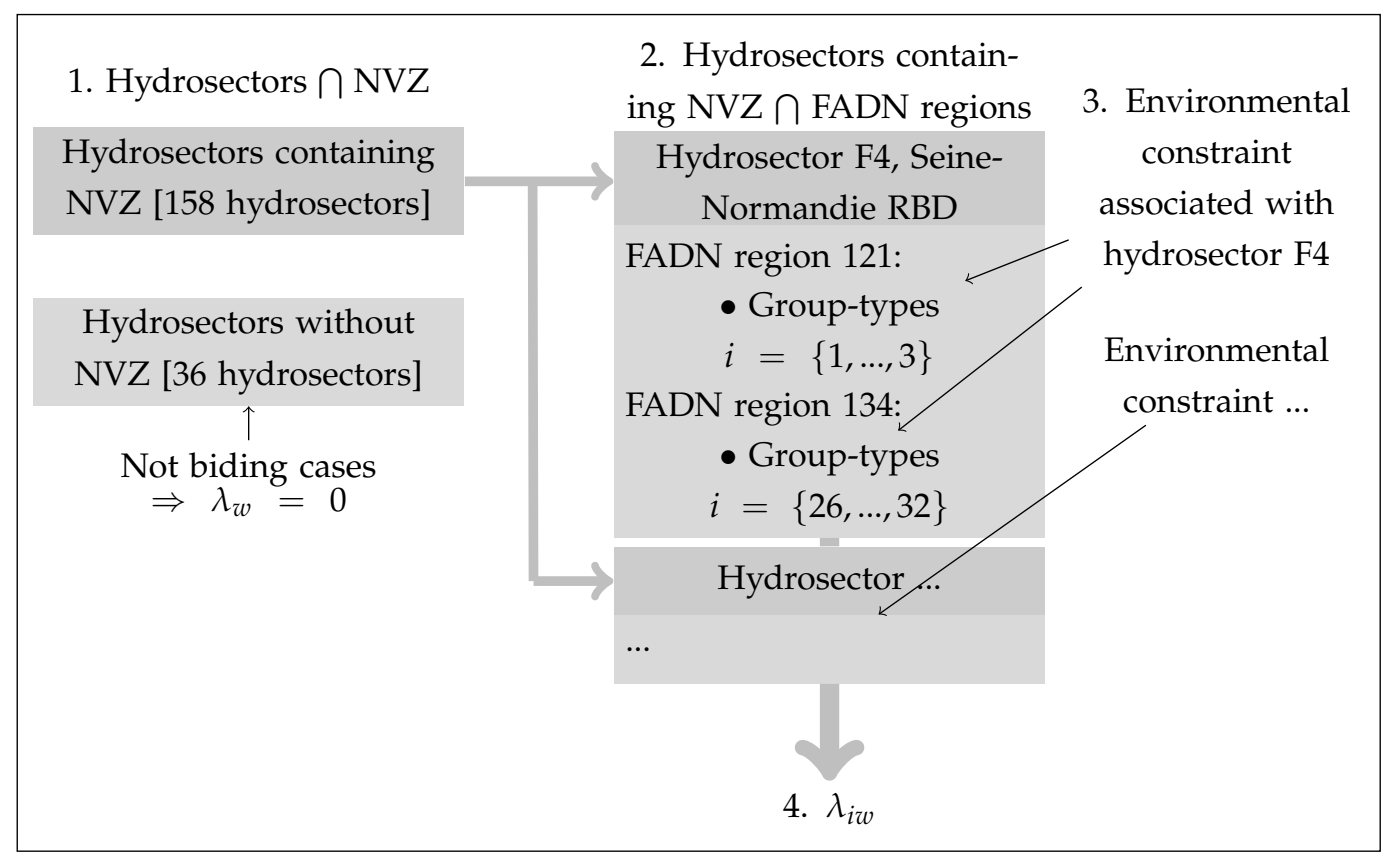

Figure 4: The modeling approach employed to estimate environmental constraint dual values. The example provided covers hydrosector F4 of the river-basin district SeineNormandie and FADN regions 121 ("Île-de-France") and 134 ("Centre"), and the associated group-types in the AROPAj model.

The modeling approach

Our modeling approach is constrained by the uncertainty of the location of economic agents. We follow the algorithm described below, summarized in Figure 4:

1. Select the hydrological sectors containing NVZs (see paragraph "Identifying the binding case" above).

2. Select the FADN regions and the associated GTs intersecting with each of the previously selected hydrosectors.

3. Introduce the environmental constraint as it is parameterized for the hydrosector in the profit maximization problem of each GT located within its borders. Thus for each GT-hydrosector combination, we perform a model simulation. Since GTs do not interact with each other in the model - each GT maximizes its gross margin individually - we cannot control for the total amount of fertilizers or livestock units. Hence, we impose the environmental constraint on each GT as if its quantity of fertilizer and number of animals were the average for the hydrosector.

4. Solve the problem and define the dual value which, under this modeling procedure, is also indexed by the GT. For a given hydrosector there are multiple values of $\lambda_{w}$ depending on the number of GTs involved.

Following Equation (5) we define farm-specific tax levels for each hydrological sector $\left(t_{i w}\right)$. This is our benchmark case. The uniform tax at the hydrological sector level is then derived by comparing farm-specific pollution fees and selecting the highest. Doing so ensures that the environmental constraint is respected for all GTs in the hydrosector in question. The other two uniform levies are defined similarly. For instance, tax rates per 
RBD are defined by selecting the highest among the taxes obtained for the hydrosectors in the basin. The uniform national rates are the highest among all taxes. The maximal charges are $€ 14.84$ per $\mathrm{kg}$ of $N$ per ha and $€ 7,986$ per LU per ha. These values are obtained for the hydrosector G7, "Le Valmont et zones côtières" on the coast of Normandy. This hydrosector is a part of the Seine-Normandie RBD.

\subsection{Results}

Table 1 summarizes the national level results for the scenarios simulated. The "No limit" case is the business-as-usual situation with animal capital varying within a $\pm 15 \%$ interval. ${ }^{14}$ The four taxation schemes correspond to the four levels of tax differentiation presented in Subsection 4.1.

\begin{tabular}{|c|c|c|c|}
\hline Scenario & Description & Gross margin & $\begin{array}{l}\text { Gross margin } \\
+ \text { tax revenues }\end{array}$ \\
\hline No limit & Business-as-usual case & $100 \%$ & $100 \%$ \\
\hline Tax GT & $\begin{array}{l}\text { Firm- and water body-specific } \\
\text { fees }\end{array}$ & $94.2 \%$ & $99.5 \%$ \\
\hline Tax hydrosectors & Uniform fee per hydrosector & $67.5 \%$ & $95.8 \%$ \\
\hline Tax RBD & Uniform fee per RBD & $-19.9 \%$ & $81.4 \%$ \\
\hline Tax National & Uniform national fee & $-199.8 \%$ & $65.6 \%$ \\
\hline
\end{tabular}

Table 1: National gross margin level for the simulated taxation schemes.

At the national level, the difference between the simulated scenarios is more pronounced when tax revenues are not taken into account (Table 1). As one would expect, the "Tax GT" is the scenario where farmers have minimum losses followed by the "Tax hydrosectors" case. The "Tax RBD" and "Tax National" scenarios result in a negative gross margin at the national level. When tax revenues are considered, the gap between the scenarios is reduced. These results very much depend on the level of the norm imposed, and on the extreme cases observed for each geographical unit considered. Thus, if the policy is aimed at compliance with the environmental norm, and the policy-maker can impose a unique tax rate at the national or RBD level, this tax rate might be unrealistic in economic terms.

To analyze the results of the different policy scenarios, we use five indicators - farmer's gross margin, tax revenue, fertilizer use, nitrate emissions, and the LU per ha - which we aggregate at the level of the six RBDs in France. Figure 5 depicts how these indicators change under different scenarios.

For all RBDs, gross margin is negative in the "Tax National" scenario. This result is based on application of the highest tax rates obtained in the simulations to all polluted areas. The sum of the gross margin and the tax revenues is positive for all RBDs and taxation schemes. In the Seine-Normandie and Loire-Bretagne RBDs, the uniform RBD rates result in a negative gross margin for farmers. The geographical disparities observed for nitrate concentrations are clearly evident in the final results. The six RBDs are divided into two groups. The Artois-Picardie, Seine-Normandie and Loire-Bretagne RBDs have the highest nitrate loads and show the greatest impact from the simulated scenarios. The

\footnotetext{
${ }^{14}$ For 12 GTs this variation is insufficient for compliance with the environmental constraint. In these cases, the number of animals is allowed to vary by more than $15 \%$. The values selected are the lowest possible for which the mathematical program provides a solution.
} 


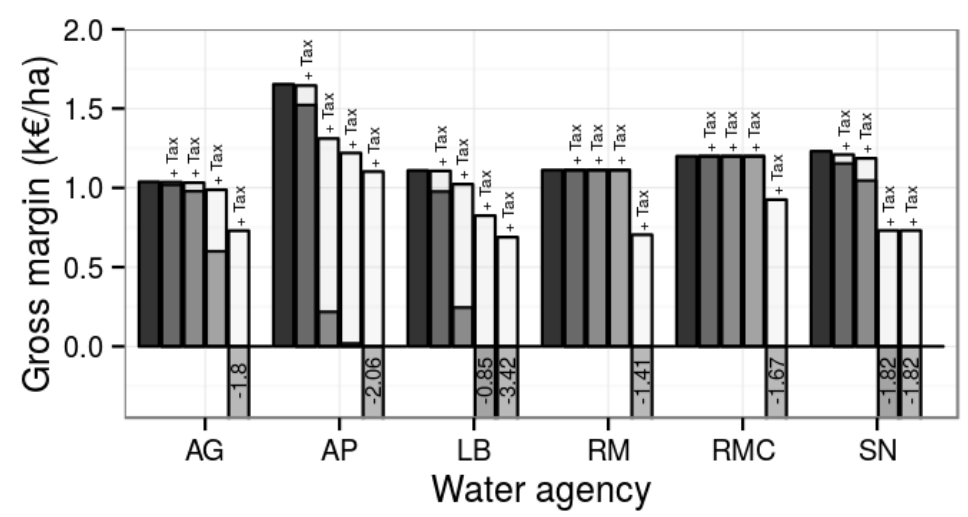

Scenario
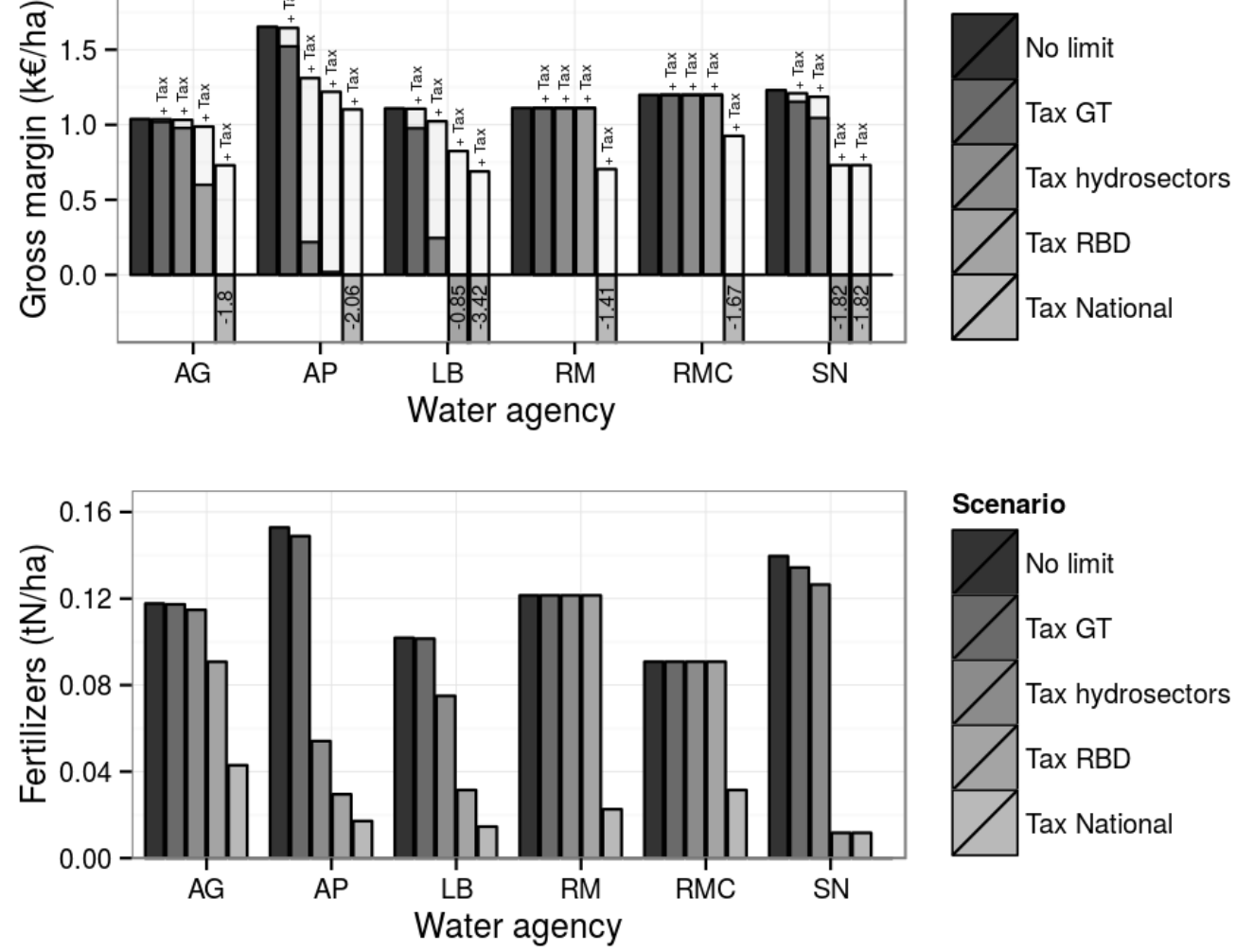

\section{Scenario}
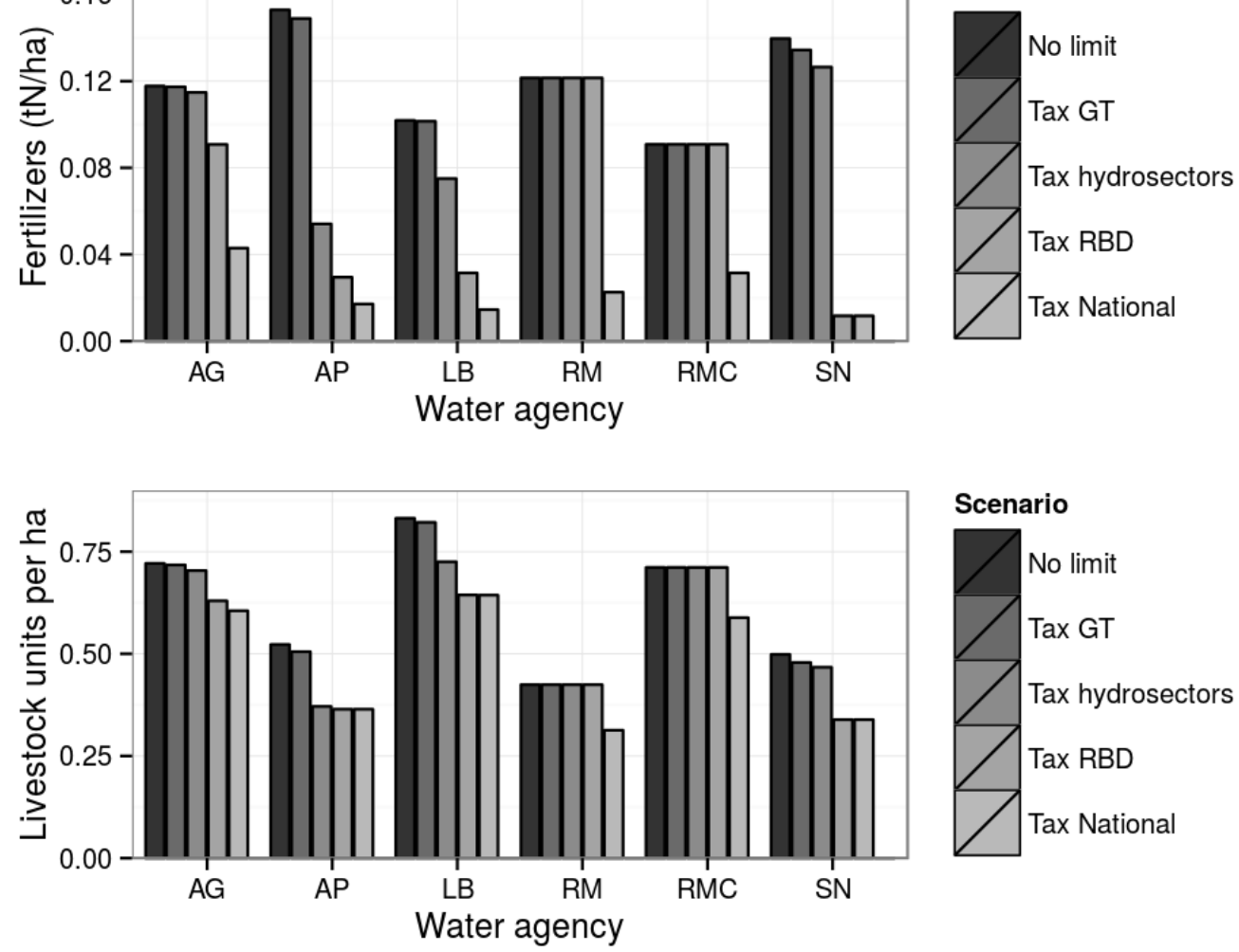

\section{Scenario}
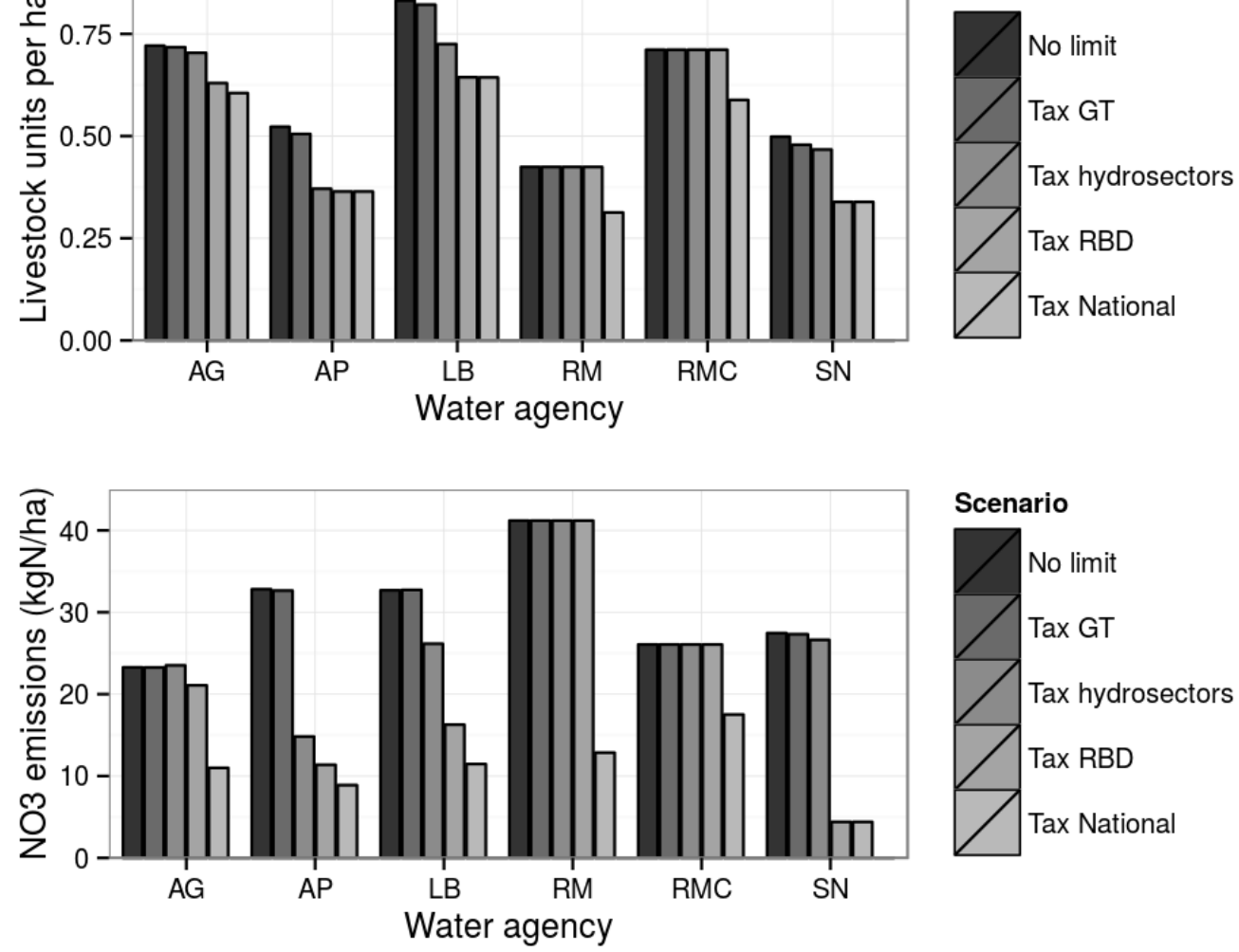

Scenario

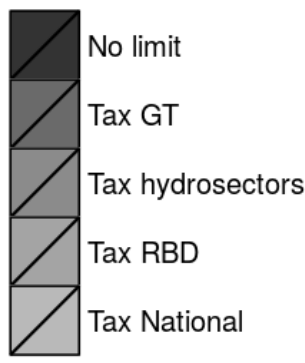

*Adour-Garonne (AG); Artois-Picardie (AP); Loire-Bretagne (LB); Rhin-Meuse (RM); RhôneMéditerranée et Corse (RMC).

Figure 5: Evolution of the indicators at the scale of the RBD under the different simulation scenarios. The top-row graph reprensents the gross margin per hectare (filled-in bars), and the sum of the gross margin and the tax revenues when taxes are applied (transparent bars marked by "+ Tax"). 
high tax values for "Tax National" and for some RBDs lead to significant abandonment of arable land (Figure 6). For example, in Artois-Picardie corn production and pasture activities are discontinued. A similar effect is observed in Seine-Normandie, where "Tax RBD" and "Tax National" have the same values for tax rates.

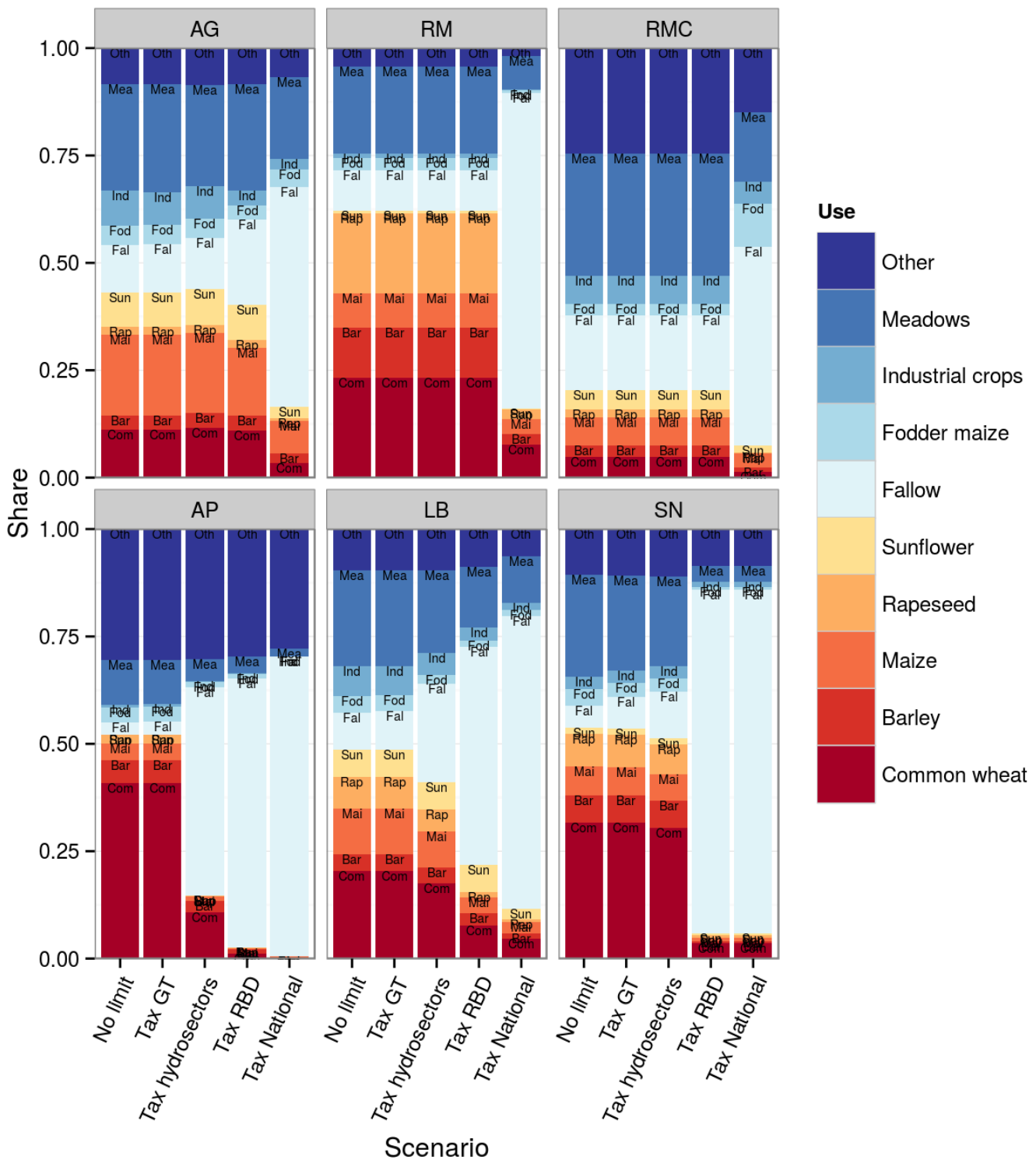

*Adour-Garonne (AG); Artois-Picardie (AP); Loire-Bretagne (LB); Rhin-Meuse (RM); RhôneMéditerranée et Corse (RMC).

Figure 6: Variation in crop areas following the simulated scenarios

The main effect of the spatial differentiation of taxation schemes is the lower charge rates applied when the fees are aimed at respecting the norm for smaller geographical areas. Furthermore, in the "Tax hydrosectors" case, pollution fees are applied only to those hydrosectors where there are GTs that infringe the environmental norm. As expected, higher tax rates generally lead to lower mineral fertilizer applications and fewer LU. By considering a greater number of geographical units and taking better account of their physical specificities, we can adjust tax levels to ensure conformity to the water quality norm and to avoid needless costs for farmers.

The two maps in Figure 7 depict the geographical distribution of the two pollution 
fees for the "Tax hydrosectors" case. The charges are higher in the Loire-Bretagne, SeineNormandie and Artois-Picardie RBDs. As already mentioned, the highest rates, which are for Seine-Normandie, are $€ 7,986$ per LU/ha and $€ 14.84$ per $\mathrm{kgN} / \mathrm{ha}$. No fees are applied to hydrosectors where there are no NVZs (for all taxation schemes simulated), or for hydrosectors where no GT has a binding environmental constraint $\left(\lambda_{i w}=0\right.$, in the "Tax hydrosectors" case depicted in Figure 7). Thus there are no environmental fees introduced in the Rhin-Meuse and Rhône-Méditerranée et Corse RBDs for the scenario considered. However, hydrosectors which include NVZs are subject to taxation under the "Tax National" scheme. Since the majority of land is devoted to cereal crops in the RhinMeuse RBD, abandonment of this type of production in the "Tax National" case leads to further abatement of $\mathrm{NO}_{3}$ emissions (Figure 5).
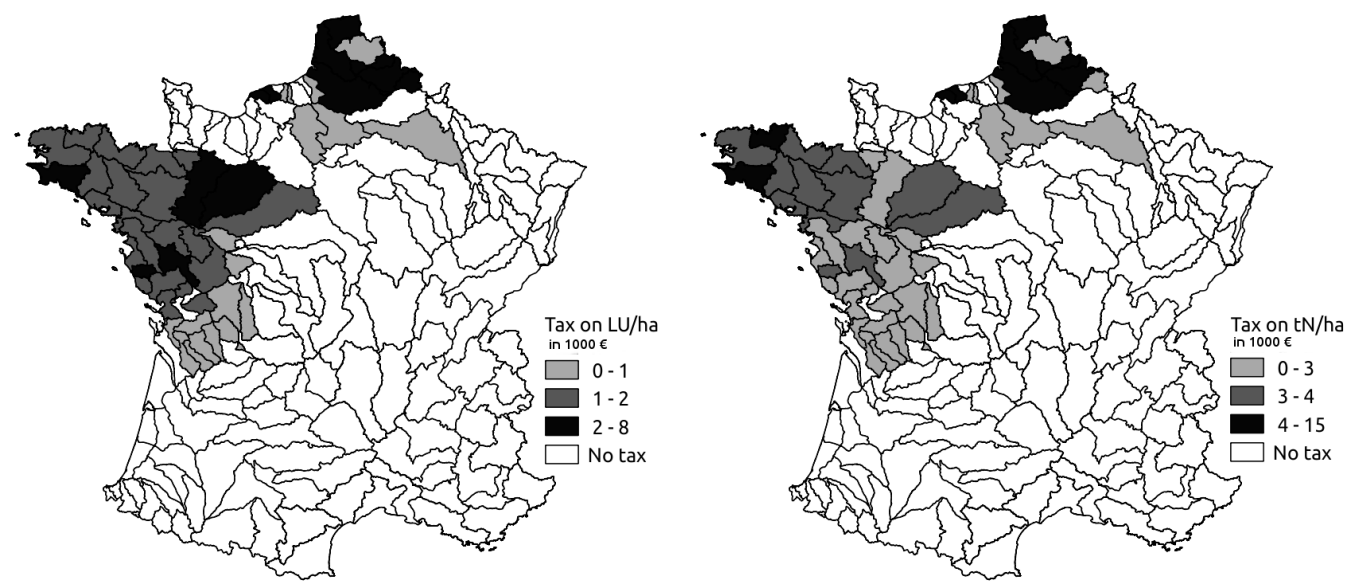

Figure 7: Geographical distribution and rates (in $€ 1000)$ for the "Tax hydrosectors" scenario

Figure 8 gives the concentrations for the four public policy scenarios at the hydrosector scale. It focuses on hydrosectors with nitrate concentration levels above $15 \mathrm{mg} / \mathrm{l}$ in the reference case. The $x$-axis gives hydrosectors in ascending order according to the reference concentration levels ("No limit"). Figure 8 shows that the concentrations resulting from the "Tax GT" scheme are mostly close to the observed concentrations, with the exception of levels close to or above $25 \mathrm{mg} / \mathrm{l}$ in the reference case. The other three taxation schemes lead to greater abatement even for lower concentration levels, since these scenarios are poorly targeted. In one hydrosector, we observe an increase in the predicted concentration of $\mathrm{NO}_{3}$ for the "Tax hydrosectors" and "Tax RBD" schemes compared to the business-as-usual case, because there is a substitution between the nitrogen from mineral fertilizers and organic nitrogen from animal manure. While quantities of mineral $\mathrm{N}$ decrease under these two policies, the number of LU/ha increases. However, the predicted nitrate concentration remains below the $25 \mathrm{mg} / \mathrm{l}$ norm for all the cases studied.

Input-based taxes on mineral fertilizers have two effects on crop production. On the one hand, they affect the quantities applied to the field (intensive margin), and on the other, they can provoke a land use switch (extensive margin). Goetz et al. (2005) focus on the interaction between these two effects and propose a land use-specific tax which limits the introduction of more polluting crops. However, the feasibility of such a policy is questionable.

When farmers adapt to new input price vectors, they can switch their activity to crops that are less demanding in nitrogen but also less efficient nitrogen fixers (more polluting), 


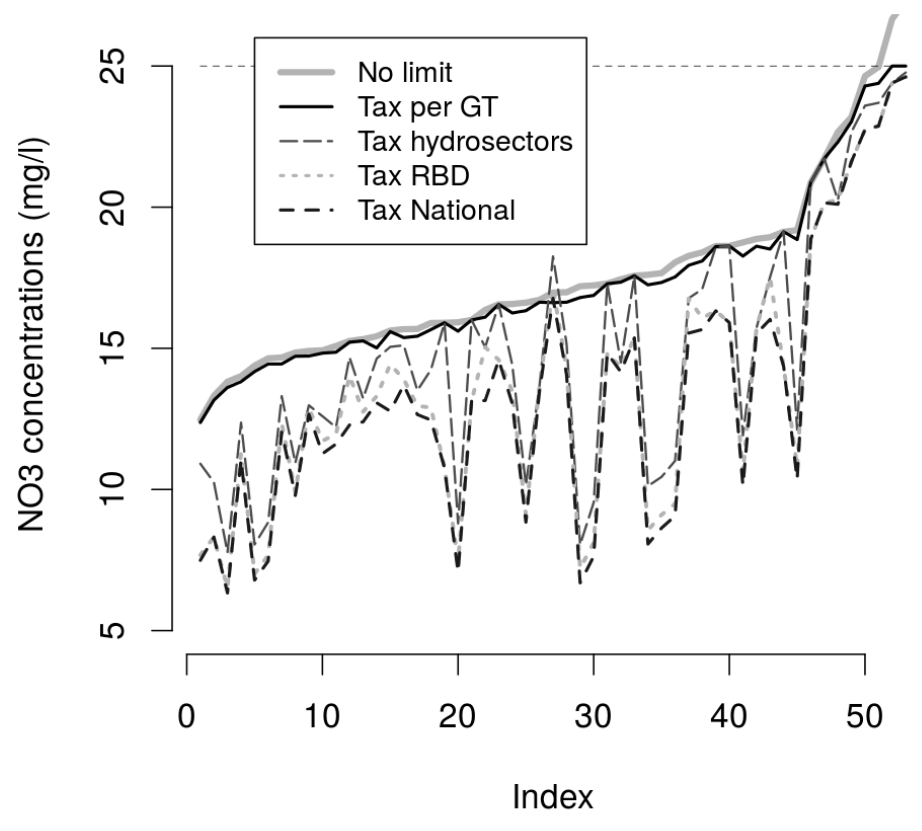

Figure 8: Reference $\mathrm{NO}_{3}$ concentrations (livestock variation and no environmental constraint) and the concentrations in the four taxation scenarios. The $\mathrm{x}$-axis is the index of hydrosectors in ascending order according to the $\mathrm{NO}_{3}$ concentrations in the reference case.

as reported in Jayet and Petsakos (2013). In this way, the quantity of nitrogen applied on fields can be reduced while real nitrate emissions increase. Our study is at the hydrosector level. Hydrosectors cover smaller territories than FADN regions. Distinguishing this effect at the hydrosector scale is easier, because this scale is closer to the real scale involved in a switching process, that is, field level.

Table 2 summarizes the number and the extent of the paradoxical effects observed in hydrosectors for the different taxation policies. In the "Tax GT" scenario, about one-sixth of the hydrosectors are affected. The percentage increase in nitrate emissions is relatively small (below $4 \%$ of the values without taxation) in most cases. Two hydrosectors in the Adour-Garonne RBD are more affected. The increase in nitrate emissions in these hydrosectors is around $26 \%$. AROPAj would allow us to simulate the effects of taxation schemes based on the estimated emissions. Under such a framework, the paradoxical effect is eliminated.

Even though the extent of this adverse effect of the taxation is fairly limited (from a national standpoint), the results show that an input-based tax policy should be accompanied by hydrosector-specific measures related to the agricultural production mix. These measures should be aimed at constraining land use change to more "polluting" crops and promoting environmentally friendly practices. Financing would be covered by tax revenues or funded from RBD agencies' budgets. For RBD agencies that support other environmental measures within their territory in accordance with the solidarity principle, transfers of this kind are common. 


\begin{tabular}{cccccccccc}
\hline & & \multicolumn{2}{c}{ Tax GT } & \multicolumn{2}{c}{ Tax hydrosectors } & \multicolumn{2}{c}{ Tax RBD } & \multicolumn{2}{c}{ Tax National } \\
RBD & All hydrosectors & Number & Percentage & Number & Percentage & Number & Percentage & Number & Percentage \\
\hline AG & 48 & - & - & 7 & $3.52 \%$ & 10 & $3.08 \%$ & 2 & $26.40 \%$ \\
AP & 7 & 5 & $0.31 \%$ & 2 & $3.29 \%$ & - & - & - & - \\
LB & 48 & 14 & $1.26 \%$ & 2 & $2.55 \%$ & - & - & - & - \\
RM & 18 & - & - & - & - & - & - & - & - \\
RMC & 29 & - & - & - & - & - & - & - & - \\
SN & 34 & 7 & $1.46 \%$ & 2 & $0.19 \%$ & - & - & - & - \\
\multicolumn{2}{l}{ CAdour-Garonne (AG); Artois-Picardie (AP); Loire-Bretagne (LB); Rhin-Meuse (RM); Rhône-Méditerranée et } \\
\multicolumn{2}{l}{ Corse (RMC) }
\end{tabular}

Table 2: Number of hydrosectors and percentage increase in nitrate emissions due to the paradoxical effect of taxation policies, defined as the case where nitrate emissions after taxation are higher than those in the "No limit" scenario, while nitrogen consumption and number of livestock units are lower.

\section{Conclusion}

We simulated a theoretically derived input-based, firm- and water body-specific tax, which enables attainment of a uniform environmental constraint. Since firm-specific taxation conflicts with the France's current legislation on the fiscal equity principle, in our case study of tax differentiation, we use water body-specific taxation rates for the two nitrogen sources, mineral and organic. These rates depend on a simplified vulnerability index and current anthropogenic pressure on water quality. Environmental policy is introduced when the environmental constraint is binding, that is, the presence of NVZs as defined in the EU Nitrate Directive (Council of the European Communities, 1991). We used an agricultural supply model (AROPAj) combined with a crop model (STICS) for our estimations. We compared four policy scenarios: 1) the benchmark case where firmand water body-specific fees are applied in polluted areas; 2) water body-specific taxes in polluted areas; 3) uniform rates per RBD in polluted areas; and 4) uniform national tax rates in polluted areas.

With regard to the RBD and national tax scenarios, the introduction of water bodyspecific rates is associated with lower gross margin losses for farmers, and better targeting of hydrosectors with high levels of nitrate concentrations. However, our results highlight the need for a case-by-case approach when addressing nitrate pollution. It would be simple to introduce tailor-made policies within the current RBD governance framework in France. French RBD agencies' management decisions are made by individual RBD committees that have existed for more than 40 years. In bringing together all the stakeholders, including farmers, they are excellent examples of "water democracy" and participative decision making. In this context, the decision to introduce a tax on mineral nitrogen fertilizers and a tax on livestock would be received more sympathetically than if these taxes were imposed directly through national legislation.

Every regulation scheme induces transaction costs related to its implementation, monitoring, and control. However, most countries have in place an administrative infrastructure at different levels that enables new levies to be introduced at relatively low additional cost. Another relevant factor is the volatility of agricultural commodity prices, which tends to limit the effectiveness in the real world of input-based taxes. Hence, the more flexible the tax the more likely it will be to achieve the desired goals. Finally, it is necessary to question the feasibility of one taxation scheme compared to another when 
implementing policy. The design of environmental regulations should take account of the focal country's institutions and legal environment, both of which can impose significant constraints on policy-makers.

Acknowledgments We are thankful to the co-editor Céline Nauges and the anonymous reviewers for their extremely useful comments, which have greatly contributed to the revised version of the manuscript. We would also like to thank Cyril Bourgeois and Athanasios Petsakos for their valuable help. Anna Lungarska acknowledges funding from French National Research Agency (ANR) under the ORACLE project (ANR-10CEPL-011) and from the PIREN-Seine research program.

\section{References}

Baumol, W. J. and Oates, W. E. (1971). The use of standards and prices for protection of the environment. The Swedish Journal of Economics, 73(1), 42-54.

Bourgeois, C., Fradj, N. B. and Jayet, P.-A. (2014). How Cost-Effective is a Mixed Policy Targeting the Management of Three Agricultural N-pollutants? Environmental Modeling $\mathcal{E}$ Assessment, 19(5), 389-405.

Brisson, N., Mary, B., Ripoche, D., Jeuffroy, M. H., Ruget, F., Nicoullaud, B., Gate, P., Devienne-Barret, F., Antonioletti, R., Durr, C., Richard, G., Beaudoin, N., Recous, S., Tayot, X., Plenet, D., Cellier, P., Machet, J.-M., Meynard, J. M. and Delécolle, R. (1998). STICS: a generic model for the simulation of crops and their water and nitrogen balances. I. Theory and parameterization applied to wheat and corn. Agronomie, 18(5-6), 311-346.

Cantelaube, P., Jayet, P.-A., Carre, F., Bamps, C. and Zakharov, P. (2012). Geographical downscaling of outputs provided by an economic farm model calibrated at the regional level. Land Use Policy, 29(1), 35-44.

Chakir, R. (2009). Spatial Downscaling of Agricultural Land-Use Data: An Econometric Approach Using Cross Entropy. Land Economics, 85(2), 238-251.

Claassen, R. and Horan, R. D. (2001). Uniform and Non-Uniform Second-Best Input Taxes. The Significance of Market Price Effects on Efficiency and Equity. Environment and Resource Economics, 19, 1-22.

Commissariat Général au Développement Durable (2011). Coûts des principales pollutions agricoles de l'eau. Commissariat Général au Développement Durable.

Council of the European Communities (1991). Council Directive 91/676/EEC of 12 December 1991 concerning the protection of waters against pollution caused by nitrates from agricultural sources.

European Community (2000). Directive 2000/60/EC of October 232000 of the European Parliament and the Council establishing a framework for community action in the field of water policy.

Fleming, R. A. and Adams, R. M. (1997). The importance of site-specific information in the design of policies to control pollution. Journal of Environmental Economics and Management, 33, 347-358. 
Gallego-Ayala, J. and Gómez-Limón, J. (2009). Analysis of policy instruments for control of nitrate pollution in irrigated agriculture in Castilla y León, Spain. Spanish Journal of Agricultural Research, 7(1).

Godard, C., Roger-Estrade, J., Jayet, P.-A., Brisson, N. and Le Bas, C. (2008). Use of available information at a European level to construct crop nitrogen response curves for the regions of the EU. Agricultural Systems, 97(1-2), 68-82.

Goetz, R.-U., Schmid, H. and Lehmann, B. (2005). Determining the economic gains from regulation at the extensive and intensive margins. European Review of Agricultural Economics, 33(1), 1-30.

Helfand, G. E. and House, B. W. (1995). Regulating Nonpoint Source Pollution under Heterogeneous Conditions. American Journal of Agricultural Economics, 77(4), 1024-1032.

Jayet, P.-A. and Petsakos, A. (2013). Evaluating the efficiency of a uniform N-input tax under different policy scenarios at different scales. Environmental Modelling $\mathcal{E}$ Assessment, $18,57-72$.

Jayet, P.-A., Petsakos, A., Chakir, R., Lungarska, A., De Cara, S., Petel, E., Humblot, P., Godard, C., Leclère, D., Cantelaube, P., Bourgeois, C., Bamière, L., Ben Fradj, N., Aghajanzadeh-Darzi, P., Dumollard, G., Ancuta, I. and Adrian, J. (2015). The European agro-economic AROPAj model. Thiverval-Grignon: INRA, UMR Economie Publique, https://www6.versailles-grignon.inra.fr/economie_publique eng/Research-work.

Kaiser, H. M., Messer, K. D. et al. (2011). Mathematical programming for agricultural, environmental and resource economics. John Wiley and Sons, Inc.

Lacroix, A., Bel, F., Mollard, A. and Sauboua, E. (2010). La territorialisation des politiques environnementales. Le cas de la pollution nitrique de l'eau par l'agriculture. Développement durable et territoires, Dossier 6: Les territoires de l'eau.

Larson, D. M., Helfand, G. E. and House, B. W. (1996). Second-Best Tax Policies to Reduce Nonpoint Source Pollution. American Journal of Agricultural Economics, 78(4), 1108.

Leclère, D., Jayet, P.-A. and de Noblet-Ducoudré, N. (2013). Farm-level autonomous adaptation of european agricultural supply to climate change. Ecological Economics, 87(0), $1-14$.

Legifrance (2014). Code de l'environnement (version consolidée au 19 mars 2014), Partie législative, Livre II, Titre Ier, Chapitre III, Section 3, Sous-section 3, Paragraphe 2 : Redevances pour pollution de l'eau, Article L213-10-2.

Martínez, Y. and Albiac, J. (2006). Nitrate pollution control under soil heterogeneity. Land Use Policy, 23(4), 521-532.

Panagos, P., Van Liedekerke, M., Jones, A. and Montanarella, L. (2012). European Soil Data Centre: Response to European policy support and public data requirements. Land Use Policy, 29(2), 329-338.

Pigou, A. C. (1937). Socialism vs. Capitalism. London: MacMillan. 
Segerson, K. (1988). Uncertainty and incentives for nonpoint pollution control. Journal of Environmental Economics and Management, 15(1), 87-98.

Service de l'observation et des statistiques (2011). Les nitrates dans les cours d'eau. Technical report, Commissariat général au développement durable.

Shortle, J. S. and Horan, R. D. (2002). The Economics of Nonpoint Pollution Control. Journal of Economic Surveys, 15(3), 255-289.

Tietenberg, T. H. (1974). Derived decision rules for pollution control in a general equilibrium space economy. Journal of Environmental Economics and Management, 1(1), 3-16.

Viennot, P., Ledoux, E., Monget, J.-M., Schott, C., Garnier, C. and Beaudoin, N. (2009). La pollution du bassin de la Seine par les nitrates. Programme PIREN-Seine.

Westra, J. and Olson, K. (2001). Enviro-economic analysis of phosphorus nonpoint pollution. In Selected Paper, 2001 Annual Meeting of the American Agricultural Economics Association, August 5-8, 2001, Chicago, IL.

Xabadia, A., Goetz, R. U. and Zilberman, D. (2008). The Gains from Differentiated Policies to Control Stock Pollution when Producers Are Heterogeneous. American Journal of Agricultural Economics, 90(4), 1059-1063.

Xepapadeas, A. (1992). Optimal taxes for pollution regulation: Dynamic, spatial and stochastic characteristics. Natural Resource Modeling, 6, 139-170. 


\section{List of Acronyms:}

EU European Union.

WFD Water Framework Directive.

$\mathrm{NO}_{3}$ Nitrate.

$N$ Nitrogen.

NPK Nitrogen (N), Phosphorus (P) and Potassium (K).

GIS Geographical Information Systems.

RBD River Basin District.

CAP Common Agricultural Policy.

NVZ Nitrate Vulnerable Zone.

FADN Farm Accountancy Data Network.

AG Adour-Garonne.

AP Artois-Picardie.

LB Loire-Bretagne.

SN Seine-Normandie.

RM Rhin-Meuse.

RMC Rhône-Méditerranée et Corse.

SPS Single Payment Scheme.

FOC First Order Condition.

IDPR Network Persistence and Development Index.

BRGM Bureau de recherches géologiques et minières. 